\title{
The Effect of Liquidity and Financial Leverage on Firm Performance: Evidence from Listed Manufacturing Firms on The Ghana Stock Exchange
}

\author{
Jiang Hongli (PhD Professor) \\ Jiangsu University, School of Finance and Economics, Zhenjiang, China \\ Elizabeth Sena Ajorsu \\ Overseas Education College \\ School of Finance and Economics, Jiangsu University, Zhenjiang, China \\ Ernest Kay Bakpa \\ https://orcid.org/0000-0002-5975-1736 \\ Overseas Education College \\ School of Finance and Economics, Jiangsu University, Zhenjiang, China
}

\begin{abstract}
This paper analyzes the effect of liquidity and financial leverage on firm performance of manufacturing industries quoted on the Ghana Stock Exchange from six different sectors from 2007-2015. We choose ROA and ROE as proxy variables for enterprise performance. We use fixed effect model and random effect model for modeling, and choose the more appropriate model. The empirical results of the study indicated that liquidity (LIQ) measured by current assets to current liabilities has a positive significant effect on return on equity (ROE) used as performance. The study finds out that the effect of financial leverage has a strong positive impact on firm performance (ROA\&ROE) with $65 \%$ of debt used to finance firm assets which in some extent has a great influence on firm performance. The study recommends management to minimize the use of debt financing and rather use more of their retained earnings for their operations to avoid bankruptcy soon.
\end{abstract}

Keywords: liquidity; financial leverage; firm performance

DOI: $10.7176 /$ RJFA/10-8-08

Publication date: April $30^{\text {th }} 2019$

\section{Introduction}

A primary concern of Liquidity and financial leverage play a significant role in the survival and success of every business organization activities, hence to function efficiently and effectively the financial managers and owners of the entity must show great concern on the outcomes of the firm performances. The term Liquidity commonly referred to the ability of an entity to change their assets into cash within the shortest possible time without losing its value. In other word, liquidity also describes the ability of an organization to strategically manage and focuses on maintaining efficient levels of current assets and current liabilities to enable the firm to have a constant flow of cash to meet its short-term obligations thus continue to exist in the foreseeable future. Another key aspect of liquidity is that it performs an important role in the existence of every firm and proper management is needed to ascertain continues cash flows for the day-to-day operation of the firms. According to Robinson et al.(2015), there are various liquidity ratios used by organizations to manage their short terms obligations and this includes current ratio, quick ratio, cash ratio, defensive interval ratio which can greatly affect the financial performance of companies. Current assets include receivable, inventory, investments for trading and cash that are continuously flowing in and out of the organizations. However current liabilities are short-term current liabilities such as accounts of creditors, that part of long-term liability during the financial year or operating cycle. Liquidity ratios indicate the capability of an entity's to settle its short-term obligations, however, the weakness of the ratios values may portray that the organization is facing some challenges in meeting their short-term debt.

More so, a primary concern of financial leverage and firm's performance decisions have remained the most crucial interesting issues among financial analysts and scholars for decades. According to Banafa et al. (2015) ,financial leverage is one of the key components of financial structure decisions, and therefore it is necessary for firm's management in developing countries to examine the pros and cons before outsourcing for their operations. Financial leverage is another sources for generating funds for financing business operations and the decisions made by both the financial manager and management can positively have an impact on firm performance through the acquisition of assets and expansion of their activities. Moreover, the decision on financial leverage can principally increase the firm profit depending on the company activities or have a negative impact on performance due to default payment of borrowed fund. Financial leverage is an external source of funds that an entity acquired to purchase more assets and finance its project without employing too much equity to operate its 
activities. Furthermore, financial leverage integrates the firm's long- term liability, short term- liability, shareholders equity and profit, which are the main sources of financing firm's activities and growth (Hasan et al.,2014).

In Ghana, a lot of manufacturing firms are facing some challenges surviving in the competitive environment due to financial issues confronting management in paying their short-terms and long-terms obligations to achieve an optimum financial structure that would minimize the firm's cost of debt and improves the firm performances. Some of these challenges are high cost of acquiring new machinery, feeding the industry with raw materials and funds needed to pay wages and salaries to workers and meeting other financial obligations which are persistently reducing the number of industries in the country. However, financial leverage and liquidity are the convenience sources of financing for manufacturing company. Meanwhile, providers of credit prefer short-term credit market to long-term market, because of the higher inflation rate in Ghana compared to other developed or emerging countries, which have the tendency of reducing the demand for future cash flows. In recent theory, most authors posit that a firm can benefits from using debt because payments of interest are not taxable and that it can increase firm performance and contrary, default payment of borrowed funds can result to bankruptcy.

Likewise, mangers are having issues on how to combine debt and equity in their operations, in order to strategically ascertain a particular combination that will efficiently minimize cost and boost manufacturing sectors performance. With the above circumstances coupled with financial distress due to illiquidity and insolvency, and other sources of financing manufacturing industry are scarce, it is therefore important that industries in Ghana have to strategically manage their capital and resources efficiently and to become profitable. The term illiquid describe the inability of a firm to settle it short-terms obligations or current expenditure whiles insolvency also refers to incapability of a firm to pay for long-terms liabilities. Furthermore, manufacturing firms in Ghana must pay more attention to efficient use of debt and liquidity management which are needed to improve performance and growth of the existing firms in solving the country's unemployment issues and ensuring economic stability. Resulting from the above challenges facing the industries, the government of Ghana has taken several steps in addressing and aimed to revive the country's manufacturing sectors to create employment and also boost the locally produced products. Therefore, management and financial managers need to have a clear guideline of whom to consult when taking decisions concerning the financial structure of the manufacturing firms. The purpose of this paper is to investigate and empirically analyze the effects of liquidity and financial leverage on the performance of manufacturing firms in Ghana. Although extensively research has been carried out on the association between liquidity and profitability, however, most scholars, financial analyst, and even management have disagreed with their findings among profit-oriented businesses.

Other schools of thought also investigated the impact of financial leverage on firm performance and concluded that debt financing can positively or negatively influence a proportion of firm performance.

Furthermore, numerous authors also attempted to explain the effects of financial leverage on firm performance, but the conclusions are quite different, which needs further study. Previous study conducted in the past shows that a number of industries in Ghana utilize debt or converting their assets into near-cash to achieve their rapid growth but the effect of liquidity and financial leverage on firm performance has not yet reached a unified conclusion. Reviews of literature reported that the study of liquidity and financial leverage on firm's performance has been conducted in the banking industries and small and medium enterprises than little can be said about the manufacturing industry. Therefore, the main objective of this study is to investigate the effects of liquidity and financial leverage on the performance of listed manufacturing firms in Ghana from 2007-2015. Furthermore, the findings of the research will guide financial managers of manufacturing firms in Ghana to analyze the financial decision impact that liquidity and financial leverage both have on firm profitability and thus, which may enable them to meet short- term and long- term financing obligations and ultimately improve their performance.

Currently, there has been just a little on the topic effect of liquidity and financial leverage on firm performance of manufacturing industries in Ghana, therefore the researchers seek the opportunity to further examined the effect about the said topic and it's important for Ghana. In Ghana, most of the manufacturing firms use financial leverage as their external source of fund for their operations but has no idea about how to use an ideal level of debt that will not negatively influence their financial performance and hence increase shareholders return. Also, many of the firm's assets are been held in liquid states which creates another problem for managers by not able to settle their short- term debt when maturity is due. All these depend on managerial skills and capability to clear their debt burden by increasing sales through exportation of locally produced goods to improve the economic conditions of Ghana. This research will serve as a tool for financial managers to analyze their financial needs, minimizes the level of debt for their operations hence generate more returns on shareholders' equity and finally improve the manufacturing performance to boost the economic growth of Ghana.

The current paper is presented as follows: section 2 presents literature reviews and hypothesis development; Section 3 outlines the research methodology, Section 4 discusses the results, and finally, section 5 concludes the paper. 


\section{Literature Review and Hypotheses development}

\subsection{The effect of liquidity on firm performance}

Most of the theoretical and empirical studies support the idea that liquidity might positively have effect on firm profitability. Lartey et al.(2013) research on the relationship between liquidity and profitability of seven banks listed on the Ghana Stock Exchange covering the period of 2005-2010. The study employs secondary data and panel method to analysis the results and concluded that liquidity has a very week positive relationship between profitability of the listed banks in Ghana. Seminal work was done by Akoto et al.(2013), they investigate the association between working capital management practices on profitability of 13 listed manufacturing firms in Ghana. The data was collected from the financial statements of listed firm on the Ghana stock exchange for the period of 2005-2009 and panel data methodology and multiple regression analysis were employs to analysis the data. The outcome of the study shows that variables like current asset ratio, cash conversion cycle, firm size, and current asset turnover reported a positive significant influence on firm performance. Base on their findings the authors recommended that management must provide an incentive for their shareholders and also the government should enact laws to protect the local manufacturing industries.

In a seminal paper, Niresh (2012) conducted a researched on 31 manufacturing firms quoted on Sri Lanka stock exchange during the period of 2007 to 2011 and examine the interaction between liquidity and profitability of the manufacturing firms. The study employs descriptive and correlation analysis and the finding of the results indicated that liquidity has no significant relationship between the profitability of Sri Lanka manufacturing firms. Furthermore,Velnampy \& Nimalathasan(2010) conducted a comparative study on firm size and profitability for some selected bank branches in Sri Lanka and conclude that there is a good relation between the size of a firm and profitability. This means that the bigger the firm size the more profit to the firm holding other factors working. In a related study, Ibe (2013) studied the impact of liquidity management on the profitability of three banks which were selected randomly in Nigeria. The author uses multiple regression analysis and Elliot Rothenberg Stock stationary test model to test for the results. The finding indicated that the Nigerian banking sectors are having challenges in managing their liquidity. Therefore, the author recommends that banks should engage competent and qualified personnel to ensure that they made the right decision and an ideal way to maximize the firm profit. Al Nimer et al. (2015) present an empirical insight into 15 Jordanian banks listed on Amman Stock Exchange and examine the impact of quick ratio on profitability in term of return on asset from 2005-2011. The study reported that quick ratio as a component of liquidity has a positive significant influenced on Jordanian bank performance (ROA).

Similarly, Justyna (2013) conducted an empirical study on the impact of liquidity on profitability in polish listed IT companies. The results of the study proved that there is a statistically positive significant relationship between liquidity and profitability in IT companies. Likewise Saleem and Rehman (2011) presented a comparative study on the impact of liquidity ratios on the profitability of oil and gas companies of Pakistan covering the period of 2004-2009. Three variables were used as a measure of profitability which includes return on asset, return on equity and return on investment whiles current ratios, liquid ratios and quick ratios were used as a liquidity ratios for the study. However, the study revealed that liquid ratio has no significant effect on ROE and ROI but has a strong significant impact on ROA, whereas other ratios of liquidity have a positive influence on profitability respectively ROA, ROE, and ROI. This study indicated that liquidity ratios play a vital role in the financial performance of very business activities. Another research was conducted by Yeo (2016) examine factors affecting solvency and liquidity of 130 shipping companies spanning from 2009-2013. The researcher uses panel data collected from Factiva database and employs GLM, FGLS and multiple regression analysis to determine factors affecting shipping firms. The paper finds that there is a high level of leverage of shipping companies which shows a negative relationship between asset liquidity. Again, the result indicated that the shipping firms were highly leveraged which has affected their performance which therefore poses a conflict between managers and investors. Further result shows that variables such as firm's age, firm size and profitability differently influence the level leverage.

Goel et al. (2015), researched on the impact of financing and operating activities of firm performance. The study was carried out in 151 Indian manufacturing firms with a 10-year panel data collected from CMIE Prowess and regression analysis was used to analysis the results. The study found a positive relationship between operating liquidity and leverage on firm performance of Indian firm. The author reported that firms that are highly geared tend to hold more liquid asset and use debt to funds their current operations. Thus, the author suggested that manufacturing firms should use a low level of debt and high liquidity to improve a firm's performance and increase shareholders worth. So we put forward the hypothesis:

H1: Liquidity has a positive significant effect on firm performance (ROA\&ROE) of listed manufacturing industries in Ghana.

\subsection{The impact of financial leverage on firm performance}

The study on debt financing plays an important role for scholars and financial managers of every organization. 
Moreover, most of the research conducted concluded that financial managers are confronted with one major issue that is how to allocate borrowed funds to the right projects in order to generate more fund to maximum return. Although numerous studies have been conducted in the past to examine whether financial leverage has a positive or negative association between firm's performances, but their studies have failed, and also some of their findings produce mixed outcomes or quite different results. Furthermore, some author's believe that financial leverage has a positive influence on a firm's performance, however, debt financing could also reduce consistent cash flow of the firm, hence increases the firm value and performances. According to Abor (2005) research on the effect of capital structure and profitability of a sample of 22 firms listed on the Ghana Stock Exchange from (1998-2002). Findings of the study show that short term debt and total debt has a strong positive relationship on return on equity whiles there is a negative relation between long term debt and ROE. The author also confirms that firm size and sale growth has a significant effect on profitability, hence concluded that $85 \%$ of the firms in Ghana depends on short term debt as the main source of financing its activities.

Similarly, Awunyo-Vitor and Badu (2012) conducted empirical research on the impact of capital structure and performance of the listed bank in Ghana for 10 years period. The data for the study were retrieved from published annual financial statement of listed banks on Ghana stock exchange where regression and panel model was used to analysis the data. The regression analysis indicated that bank capital structure is closely related to the firm performance (ROE \& Tobin's q) however, the study also shows a high level of financial leverage which negatively affects banks performance and a consistent dependency can contribute high risk in the bond market. Amidu (2007) also examine the dynamics involved in the determination of financial leverage on profitability of 19 listed banks in Ghana during the period 1993-2003. The paper found that total debt has a negative significant relationship on the profitability of banks listed on Ghana stock exchange. Further studies reported that other variables such as profitability, corporate tax, growth, asset structure, and bank size influence banks' financing decision. Other studies have been done in different part of the world and came out with their own findings. In a related study, Bui (2017) conducted a research on 18 British Gas and Oil companies and investigate the effects of debt financing on performance by using published data from financial statements from 2009 to 2014. The result indicated a strong negative impact of leverage on performances of ROA and ROE, of those firms. Based on the findings, the researcher concluded that firms that rely on debt for financing its operations exhibit poorer performances, therefore in order to maximize profit, the author advice firm's management to carefully consider how to use optimal level of debt to eliminate elements of bankruptcy cost and maximized profit.

According to Ibhagui and Olokoyo (2018) investigated the relationship among financial leverage, company size and performance of 101 listed pharmaceutical firm in Nigeria covering the period of 2003-2007.Using a threshold model the result of the of the study indicated that leverage has a negative effect on performance of small and medium size firm but rather increases the performance of firms that grow bigger irrespective of amount of debt used in Nigeria listed firms. A further study conducted by Raza (2013), researched on the topic effect of financial leverage on company performance of 482 non-financial industries quoted on Karachi Stock Exchange (KSE) from the period of 2004-2009. The author employs panel data and regression analysis for the study and found out that the value for leverage ratios for textile industry is very high therefore have a negative effect on their performance due to the high level of debt. The author also reported that the above result constitutes to high cost of borrowing which has resulted in the low profitability of the textile industries. Similarly, Chadha and Sharma (2015) conducted 10 years researched on 422 listed Indian manufacturing firms to examine the impact of leverage on firms financial performance. The paper uses three proxy for measuring financial performance which includes return on asset, return on equity and Tobin's Q. The study found that leverage has no significant impact on two of the performance ratios namely return on asset and Tobin's Q respectively whereas it is significantly correlated to return on equity with other variables such as firm age, firm size, sale growth, and asset turnover are a good predictor of financial performance of Indian manufacturing sectors.

Following Shubita and Alsawalhah (2012) analyze the impact of financial leverage on the profitability of manufacturing firms quoted on the Amman Stock Exchange for six-year (2004-2009). The study was carried out in 39 companies using correlations and multiple regression analysis to analyze the result. The author found a negative significant relationship between debt and profitability of the firm and concluded that profitability increases with firm size and sales growth used as a control variable for the study. And also recommend management to pay more attention to their financing decision to avoid high indebtedness. According to Banafa et al. (2015) explored the impact of financial leverage on the financial performance of 42 listed non-financial firms in Kenya covering the period of 2009-2013 from different sectors. The paper uses causal research design and panel data model, and the empirical result shows that leverage had a negative significant impact on corporate financial performance. Again the author reported that greatest proportions of the firm's resources or assets were financed through long term debt.

Pouraghajan et al. (2012) reviewed the effect of financial leverage on the financial performance of 400 companies in Iran. The study was conducted on 12 different industries with data collected from the annual financial statement of firms quoted on Tehran stock exchange covering the period of 2006-2010. The finding of the study 
indicated that leverage ratios have a strong negative effect on performance (ROA \& ROE) of Iranian firms. They also reported that the following variables; asset turnover ratio, firm size, assets tangibility, and growth opportunities have a positive significant relation with measures of financial performance on companies. Through the above empirical analysis on the effect on firm performance, we can conclude that most scholars have different outcomes on the said topic. Furthermore, some authors also argue out that the impact of financial leverage on firms performance can be associated with or affected by numerous factors such as firm asset tangibility, ownership structure, and growth opportunity. Thus, in this study we predict that financial leverage will have a positive significant effect on firm performance. So we put forward the hypothesis:

H2: Financial leverage has a positive correlation effect on firm performance (ROA \& ROE) of listed manufacturing industries in Ghana.

\section{Research method}

\subsection{Sample and Data Collection}

The sample size consists of 22 manufacturing firms quoted on the Ghana Stock Exchange covering the period from 2007-2015. The paper examines manufacturing firms from six different sectors listed on Ghana stock exchange including Wood and Processing, Beverage and Pharmaceutical industries, Trading and Information Technology, Manufacturing and Paper converters, Metal and Oil, and Agriculture and Agro processing. The purpose of the study is to empirically investigate the effects of liquidity and financial leverage on the performance of listed manufacturing firms in Ghana. All other manufacturing firms which are not quoted are excluded from this study, however, the data was interpreted by using matrix correlations, descriptive statistics and Fixed Effect model with the aid of STATA 14. The study uses panel data for the research because it combines both time series and cross sectional data hence it is expected to give unbiased estimators. Also, the panel data model gives researchers greater flexibility to control the impact of individual-specific variables and time-specific variables Baltagi, Egger, and Pfaffermayr (2014). The data for the study was collected and retrieved from the audited annual financial reports, Fact Book of Ghana Stock Exchange and from the web portals of individual firms. The data were collected from the annual financial statement of manufacturing industries quoted on Ghana Stock Exchange from the period 2007-2015.

\subsection{Regression model}

The main aim of this paper is to measure the effect of independent variables on firm financial performance, by using multiple regression equations. It then follows;

$$
\begin{gathered}
R O A_{i, t}=\alpha_{10}+\alpha_{11} L I Q_{i, t}+\alpha_{12} \log F S_{i, t}+\alpha_{13} F A_{i, t}+\alpha_{14} S G_{i, t}+\varepsilon_{i, t} \\
R O A_{i, t}=\beta_{10}+\beta_{11} F L E V_{i, t}+\beta_{12} \log F S_{i, t}+\beta_{13} F A_{i, t}+\beta_{14} S G_{i, t}+\varepsilon_{i, t}
\end{gathered}
$$

Where, ROA is firm return on assets, $\alpha_{0}$ is a constant, $L I Q_{i, t}$ stands for Liquidity of a firm at time t,FLEV $V_{i, t}$ stand for Financial Leverage of a firm at time $\mathrm{t}, \log F S_{i, t}$ represent the logarithm of firm size at a time t,F $A_{i, t}$ stands for firm age at time t, $S G_{i, t}$ stands for firm sale growth at time $\mathrm{t}$ and $\varepsilon_{i}$ is the error term.

$$
\begin{aligned}
R O E_{i, t} & =\alpha_{20}+\alpha_{21} L I Q_{i, t}+\alpha_{22} \log F S_{i, t}+\alpha_{23} F A_{i, t}+\alpha_{24} S G_{i, t}+\varepsilon_{i, t} \\
R O E_{i, t} & =\beta_{20}+\beta_{21} F L E V_{i, t}+\beta_{22} \log F S_{i, t}+\beta_{23} F A_{i, t}+\beta_{24} S G_{i, t}+\varepsilon_{i, t}
\end{aligned}
$$

Where, ROE is a firm return on equity.

\subsubsection{Dependent variables}

Return on Assets and Return on Equity (ROA\&ROE) are the explanatory variables used as a proxy for measuring the performance of manufacturing firms listed on Ghana stock exchange. Return on Asset (ROA) is a tool used to measures how effectively a company earns income from its assets. Therefore, high values of ROA indicate that companies are making efficient use of their assets to generate more returns. This is calculated as dividing net operating profit by total asset. The second variable, Return on Equity (ROE) is a tool that strategically measures the capability of a company to generate returns on shareholders' equity. Ang and Bekaert (2006) argue that a higher ratio of Return on Equity (ROE) determines the returns on shareholders' investment and growth of the business. Furthermore, ROE is a key performance ratio that shows the fact about company ability to generate enough return to compensate for the risk taken. This is calculated as the net operating income divided by shareholders equity.

\subsubsection{Independent variables}

Financial leverage

According to Bae et al. (2017) defined financial leverage as a proportion of a firm's total debt to total assets which comprises of long -term liability that matured within an accounting year. Thus firms that are highly geared utilize more debt than other sources for financing their projects and operations. Likewise, firms that utilized low level of financial leverage indicated that their source of financing is either through retained earnings or equity financing. 
Financial leverage can be computed as dividing total debt to the total asset.

Liquidity

According to pecking order theory, opinion that firms that are highly liquid are required to use their retained earning capital other than using external financing (Khémiri \& Noubbigh, 2018). However, liquidity is the ability of an entity to meet its short-term obligation and consistently has free flows of cash. Therefore, the variable liquidity can be calculated by dividing the ratio of current assets to current liabilities (LIQ). This ratio has been used by a number of scholars Khan (2012).

Table1. Variable definitions and descriptions

\begin{tabular}{ll}
\hline Variables & Description \\
\hline Return on asset (ROA) & profit after tax / total asset \\
Return on equity (ROE) & profit after tax/shareholders' equity \\
Financial leverage (FLE) & total debt / total assets \\
Liquidity (LIQ) & current asset / current liabilities \\
Firm size (FS) & natural logarithm of total assets \\
Firm Age (FA) & current year - the year of incorporation \\
Sales growth (SG) & current year's sale minus previous years divided by previous year's sale \\
\hline
\end{tabular}

\subsection{Control variables}

This paper uses three control variables which include firm size, firm age, and sales growth for the study. Firm size greatly has a positive impact on firm performance due to the diversification of resources and also the benefit they enjoy by producing on a large scale to reduce production cost. Following Alzomaia (2014) argues that large firms can easily access loans from a financial institution because their probability of default payment is very low compared to other small firms. From a trade-off point of view, the size of a firm is associated with risk and insolvency(Eriotis et al,2007). According to Awuah-Agyeman(2016), argue that a firm's age is considered an acceptable yardstick to assess social image in its capital structure models. A firm that exists in operations for a longer period of time, continuously build a good business reputation or goodwill in terms of their products and management skills and its credit worthiness can easily de assessed by external fund providers. Therefore as firm ages, it expands its capability to acquire more debt; therefore it is expected that firm age has a positive relation to debt (Abor, 2008). Firm age, therefore, can be computed as the current year in the existing minus year of incorporation. Moreover, Salim \& Yadav(2012) assert that sales growth of a firm will significantly affect the firm's performance, thus sales growth of the firm is measured by changes in total sales.

\section{Empirical analysis result}

4.1 Descriptive statistical analysis

Table 2. A descriptive statistic

\begin{tabular}{|c|c|c|c|c|c|c|c|}
\hline Variables & Mean & $\begin{array}{l}\text { Standard } \\
\text { deviation }\end{array}$ & Minimum & Maximum & Variance & Skewness & Kurtosis \\
\hline $\begin{array}{l}\text { Return on asset } \\
\text { (ROA) }\end{array}$ & 12.8384 & 2.6988 & 3 & 15 & 7.2834 & -1.9763 & 6.7366 \\
\hline $\begin{array}{l}\text { Return on equity } \\
\text { (ROE) }\end{array}$ & 11.7980 & 3.2336 & 3 & 15 & 10.4564 & -1.1788 & 3.5175 \\
\hline $\begin{array}{l}\text { Financial Leverage } \\
\text { (FLEV) }\end{array}$ & 11.9191 & 2.4210 & 3 & 14 & 5.8615 & -2.0893 & 7.3429 \\
\hline Liquidity (LIQ) & 11.8889 & 2.8244 & 5 & 15 & 7.9774 & -1.1184 & 3.3777 \\
\hline Firm Size (FS) & 10.3535 & 3.4281 & 3 & 16 & 11.7526 & -.2577 & 1.5184 \\
\hline Firm Age (FA) & 8.6061 & 1.9709 & 3 & 11 & 3.8846 & -1.1456 & 3.0803 \\
\hline Sale Growth (SG) & 24.3383 & 5.7557 & 7 & 34 & 33.1286 & -1.0789 & 3.7033 \\
\hline
\end{tabular}

Table 2 gives a descriptive statistic of all the twenty-two listed manufacturing firms in Ghana for the period of 2007-2015 for a total of 198 observations. From table 2, it is deduced that profit before tax to total asset which is a return on asset (ROA) has a mean value of $12.84 \%$ with a standard deviation of $2.70 \%$. Again, the descriptive analysis of return on equity (ROE) as a measure of financial performance has a mean value of $11.80 \%$ and with a standard deviation of $3.23 \%$. The very low percentage signifies that shareholders are receiving very low value for their investments in terms of equity. Furthermore, the descriptive statistics show that during the period under review, total debt to the total asset as measures of financial leverage has the mean value of $11.92 \%$ with a deviation of $2.42 \%$. The debt ratio reveals that Ghanaian manufacturing industries assets are financed by $11.92 \%$ of debt with is very low. Also, descriptive statistics further shows that liquidity (LIQ) in terms of a current asset to current liabilities ratio is about $11.89 \%$ and have a standard deviation of $2.82 \%$ this portrays cash flow to pay for short terms obligations. The logarithm of a total asset which is used to measure firm size (FS) as a control variable has a mean value of $10.35 \%$ with a standard deviation of $3.42 \%$. The descriptive statistics further shows firm age 
having a mean value of $8.61 \%$ and with a standard deviation of $1.97 \%$. In addition, the descriptive statistics of sales growth (SG) has a mean value of $24.34 \%$ and a standard deviation of $5.76 \%$. The high mean of sales growth indicated that manufacturing companies have a higher rate of return on their sales thus increases a firm's performance. In, a conclusion the values of skewness show negatively skewed values of all the variables in the table used to measured firm performance.

Table 3. The correlation coefficient of the variables

\begin{tabular}{llllllll}
\hline & ROA & ROE & FLEV & LIQ & FS & FA & SG \\
\hline ROA & 1.0000 & & & & & & \\
ROE & 0.9193 & 1.0000 & & & & & \\
FLEV & 0.9652 & 0.9225 & 1.0000 & & & & \\
LIQ & 0.8400 & 0.9335 & 0.8873 & 1.0000 & & & \\
FS & 0.7924 & 0.8110 & 0.7539 & 0.7496 & 1.0000 & & \\
FA & 0.8574 & 0.9066 & 0.8135 & 0.8520 & 0.8426 & 1.0000 & 1.0000 \\
SG & 0.9355 & 0.9727 & 0.9232 & 0.9044 & 0.8395 & 0.9108 & \\
\hline
\end{tabular}

From the correlation matrix, it shows that the relation between financial leverage (FLEV) and return on asset (ROA) has a strong positive coefficient of $97 \%$. This implies that the company debt has contributed to a $97 \%$ return on asset. Also, the correlation matrix of FLEV on ROE is at 92\%. This result indicates, that FLEV has a strong positive significant effect on return on shareholders' equity. It can be observed that the liquidity (LIQ) in term of the current asset has contributed to $84 \%$ on ROA. This result implies that in the short-term the company's solvency increases which cause a rise in the firm ROA. Likewise, LIQ has a great positive impact on return on equity with a coefficient of $93 \%$. Furthermore, the result depict a positive correlation between firm size (FS) on the variables used to measure firm performance (ROA\&ROE) with a coefficient of $79 \%$ and $81 \%$ respectively. This result also shows that firm size has a great influence on firm performance in terms of production and benefit from economies of scale. More so, the correlation result of firm age on firm performance (ROA\&ROE) also has a strong coefficient of $86 \%$ and $91 \%$. This indicates that the number of years in business increases the firm reputation and credit worthiness and profit. The high rate of sale growth on performance implies that there has been an increase in revenue which contributed to a significant impact on firm performance.

Table 4. Hausman fixed random for ROA

\begin{tabular}{lllll}
\hline & $(\mathrm{b})$ & $(\mathrm{B})$ & $(\mathrm{b}-\mathrm{B})$ & \\
& Fixed model & Random model & Difference & $\begin{array}{l}\text { sqrt(diag(V_b- } \\
\text { V_B }) \text { S.E. }\end{array}$ \\
\hline $\begin{array}{l}\text { Financial Leverage } \\
\text { (FLEV) }\end{array}$ & 0.7982 & 0.7993 & -0.0011 & 0.0117 \\
Liquidity (LIQ) & -0.0435 & -0.0356 & -0.0079 & 0.0142 \\
Firm Size (FS) & 0.0280 & 0.0328 & -0.0049 & 0.0068 \\
Firm Age (FA) & 0.1705 & 0.1740 & -0.0034 & 0.0148 \\
Sale Growth (SG) & 0.0591 & 0.0576 & 0.0016 & 0.0088 \\
\hline
\end{tabular}

From the Hausman test of both random and fixed effect, the probability chi2 which is less than 0.05 , show that the best model for estimating the main effect on firm performance is the fixed effect model. The condition for the selection of either effect is if the prob $>$ chi2 is less than 0.05 or equal to 0.05 , hence the selection of the fixed effect model.

Table 5. Hausman fixed random for ROE

\begin{tabular}{lllll}
\hline & $(\mathrm{b})$ & $(\mathrm{B})$ & $(\mathrm{b}-\mathrm{B})$ & sqrt(diag(V_b-V_B $))$ S.E. \\
& Fixed model & Random model & Difference & \\
\hline Financial Leverage (FLEV) & 0.2371 & 0.2549 & -0.0178 & 0.0131 \\
Liquidity (LIQ) & 0.3207 & 0.3207 & 1.3915 & 0.0000 \\
Firm Size (FS) & -0.0337 & -0.337 & 9.7816 & 0.0076 \\
Firm Age (FA) & 0.1317 & 0.1317 & -3.2815 & 3.4209 \\
Sale Growth (SG) & 0.3792 & 0.3792 & -1.1116 & 0.0099
\end{tabular}

From the Hausman test of both random and fixed effect, the probability chi2 which is less than 0.05 , show that the best model for estimating the main effect is a fixed effect. The condition for the selection of either effect is if the prob $>$ chi 2 is less than 0.05 or equal to 0.05 , we chose the fixed effect model to run the regression but if the prob $>$ chis 2 is more than 0.05 we chose the random effect for the estimation. The Hausman test also shows that the right model to use is the fixed effect. This is based on the probability chi2 which is more than 0.05 for all the 22 manufacturing firms in Ghana. 
Table 6. Regression results of ROA \& ROE on Financial Leverage (FLEV)

\begin{tabular}{lll}
\hline & $(\mathrm{RE})$ & $(\mathrm{RE})$ \\
VARIABLES & ROA & ROE \\
\hline Financial Leverage (FLEV) & $0.645^{* * *}$ & $0.387^{* * *}$ \\
Firm Size (FS) & $(0.050)$ & $(0.071)$ \\
& -0.007 & -0.021 \\
Firm Age (FA) & $(0.025)$ & $(0.035)$ \\
& $0.203 * * *$ & $0.236^{* * *}$ \\
Sale Growth (SG) & $(0.055)$ & $(0.077)$ \\
& $0.082^{* * *}$ & $0.237 * * *$ \\
Constant & $(0.024)$ & $(0.034)$ \\
& $1.496^{* * *}$ & -0.396 \\
R-sq & $(0.523)$ & $(0.643)$ \\
Prob > chi2 & 0.947 & 0.951 \\
sigma_u & 0.000 & 0.000 \\
sigma_e & 0.587 & 0.556 \\
Rho & 0.294 & 0.361 \\
\hline
\end{tabular}

Standard errors in parentheses, $* * * p<0.01, * * p<0.05, * p<0.1$

From table 6, the multiple regression analysis shows that the explanatory variable financial leverage (FLEV) in terms of total debt has a strong significant effect on return on asset (ROA). The significant effect of total debt on firm ROA indicates that the assets which are financed by debt have greater returns of $65 \%$ and is significant at 0.01. More so, the variable Liquidity (LIQ) also have a positive impact on firm performance (ROE) with an increase of $39 \%$ and significant level of 0.001 . Furthermore, from the above table 6, Firm size (FS) which is measured by the logarithm of total assets has a negative insignificant effect on firm performance (ROA\&ROE), which have the coefficient of -0.007 and -0.021 respectively at a p-value of 0.001 . Likewise, firm age (Fage) has a positive effect on return on equity (ROE) and at a significant value of 0.01 . In addition, it can be observed that Sale growth (SG) has a strong positive effect on firm performance (ROA) with an increase of $8 \%$ at 0.01 significant level. Consequently, Sale growth (SG) is a significant predictor of Return on equity (ROE) at $24 \%$ which is statistically significant at 0.05 level. Thus, this shows a very strong significant positive effect of Sale growth on return on asset (ROE).

Table 7. Regression result of ROA \&ROE on Liquidity (LIQ)

\begin{tabular}{lll}
\hline & $(1)$ & $(2)$ \\
VARIABLES & ROA & ROE \\
\hline Liquidity(LIQ) & -0.024 & $0.255^{* * *}$ \\
Firm Size(FS) & $(0.049)$ & $(0.051)$ \\
& $0.0943^{* * *}$ & -0.003 \\
Firm Age(FA) & $(0.033)$ & $(0.035)$ \\
& $0.214^{* * *}$ & $0.249^{* * *}$ \\
Sale Growth(SG) & $(0.075)$ & $(0.077)$ \\
& $0.237^{* * *}$ & $0.296^{* * *}$ \\
Constant & $(0.030)$ & $(0.032)$ \\
& $4.530^{* * *}$ & -0.549 \\
\hline R-sq & $(0.748)$ & $(0.508)$ \\
Prob $>$ chi2 & 0.862 & 0.962 \\
sigma_u & 0.000 & 0.000 \\
sigma_e & 0.944 & 0.430 \\
Rho & 0.386 & 0.378 \\
Standard errs & 0.857 & 0.563 \\
\hline
\end{tabular}

Standard errors in parentheses, $* * * \mathrm{p}<0.01, * * \mathrm{p}<0.05, * \mathrm{p}<0.1$

From the multiple regression analysis, it can be observed that the independent variable Liquidity (LIQ) have no impact on the return on asset (ROA). This means that a unit increase in the level of Liquidity will lead to $2 \%$ decrease on firm performance. The decrease in the value shows negative insignificant effects on firm performance at 0.01 which is less than 0.05 . It can also be observed that Liquidity (LIQ) is a good predictor of return on equity (ROE) at $26 \%$ with a significant level of 0.01 . This result means that at least $26 \%$ of the firm's short-term obligations can be met when their assets are converted back to cash and increases the worth of shareholders equity. Secondly, Firm size (FS) has increased to $9 \%$ and is significance at 0.01 , and this is the best predictor of Return on Assets (ROA). This means that there is a highly significant positive effect on return on asset (ROA). On the other hand, Firm size has a negative insignificant influence on return on equity at 0.01 significant level. 
Furthermore, the analysis also indicated that the age of a firm significantly have a positive influence on firm performance (ROA\&ROE) $21 \%$ and $25 \%$ respectively at a significant level of 0.01 . Similarly, Sale growth (SG) has contributed to a $24 \%$ increase on the return on assets of the firm and $30 \%$ increment on return on equity (ROE).

From the study, the hypothesis that state that liquidity has a positive impact on a firm's performance (ROE), is accepted based on the profitability " $F$ " test which is 0.000 . Also, we accept the second hypothesis that state that financial leverage has a positive effect on firm performance (ROA\&ROE). We, however, reject the alternative hypothesis which states that liquidity has a positive influence on return on asset (ROA) on a manufacturing industry listed on the Ghana Stock Exchange.

\section{Conclusion}

The study on Liquidity and financial leverage in the manufacturing firms are the common issues facing the survival and operations of firm performance with which information on them are seriously hidden. This paper investigated the effect of liquidity and financial leverage on the performance of manufacturing firms quoted on the Ghana Stock Exchange from six different sectors. The statistical results of the study indicated that liquidity (LIQ) measured by current assets to current liabilities has a positive significant effect on return on equity (ROE) used as proxy firm performance. This result means that financial managers of the manufacturing industries meet their short terms obligation thus improved the firm's performance, while liquidity (LIQ) shows a negative insignificant impact on return on asset. A further study reported that financial leverage ratio shows a strong positive significant influence on firm performance (ROA\&ROE) with $65 \%$ of debt used to finance asset which in some extent has a great impact on firm performance. Although debt financing can result to a decline in firm performance, however, shareholders of manufacturing firms must work hard to avoid the risk caused by either short terms or long terms debts thus effectively use them to promote the growth and performance. Result of the empirical studies also shows that sales growth significantly and positively affects firm performance, this finding implies that listed manufacturing firms in Ghana will extremely improve their performance when they increase their sales.

Based on our empirical results, the researchers therefore suggest that management should reduce or eradicate the problems associated with liquidity and financial leverage on firms' performance in the manufacturing sectors in Ghana and also applicable to other countries. Managers of manufacturing firms should adopt a prudent way to resolve their liquidity issues hence ensure that current assets and current liabilities of the firm must be maintained at an ideal level since it can influence how short-term obligations are honored. More so they should also avoid holding more of their assets in the liquid state for unexpected demands from suppliers and other recurrent expenditures hence, find a better way to attend to such demands. A retained earnings and shareholders dividend should be use to settle those obligations. In addition, financial manager should adopt an optimal capital structure to control the scale of debt financing, so as not to increase the risk caused by excessive debt that brings adverse effects on firm's performance but rather to maximize shareholders equity. The study recommended that government should support local manufacturing firm by giving them subsidies for borrowing and enactments laws to protect the local manufacturing firms and to restrict the activities of importers thus promote high demand for locally manufactured goods to increase the economic growth in Ghana.

\section{References}

Abor, J. (2005). The effect of capital structure on profitability: an empirical analysis of listed firms in Ghana. The journal of risk finance, 6(5), 438-445.

Abor, J. (2008). Determinants of the capital structure of Ghanaian firms.

Akoto, R. K., Awunyo-Vitor, D., \& Angmor, P. L. (2013). Working capital management and profitability: Evidence from Ghanaian listed manufacturing firms.

Al Nimer, M., Warrad, L., \& Al Omari, R. (2015). The impact of liquidity on Jordanian banks profitability through return on assets. European Journal of Business and Management, 7(7), 229-232.

Alzomaia, T. (2014). Capital structure determinants of publicly listed companies in Saudi Arabia.

Amidu, M. (2007). Determinants of capital structure of banks in Ghana: an empirical approach. Baltic Journal of Management, 2(1), 67-79.

Ang, A., \& Bekaert, G. (2006). Stock return predictability: Is it there? The Review of Financial Studies, 20(3), 651-707.

Awuah-Agyeman, D. (2016). Assessing the impact of capital structure on profitability of manufacturing industry in Ghana: A case study at selected firms.

Awunyo-Vitor, D., \& Badu, J. (2012). Capital structure and performance of listed banks in Ghana. Global Journal of Human-Social Science Research, 12(5).

Bae, J., Kim, S. J., \& Oh, H. (2017). Taming polysemous signals: The role of marketing intensity on the relationship between financial leverage and firm performance. Review of Financial Economics, 33(1), 29-40.

Baltagi, B., Egger, P., \& Pfaffermayr, M. (2014). Panel data gravity models of international trade.

Banafa, A., Muturi, W., \& Ngugi, K. (2015). The impact of leverage on financial performance of listed non- 
financial firm in Kenya. International Journal of Finance and Accounting 4 (7), 1, 20, 2009-2013.

Bui, N. T. H. (2017). The impact of financial leverage on firm performance: A case study of listed oil and gas companies in England. International Journal of Economics, Commerce and Management, 5(6), 477-485.

Chadha, S., \& Sharma, A. K. (2015). Capital structure and firm performance: Empirical evidence from India. Vision, 19(4), 295-302.

Eriotis, N., Vasiliou, D., \& Ventoura-Neokosmidi, Z. (2007). How firm characteristics affect capital structure: an empirical study. Managerial Finance, 33(5), 321-331.

Goel, U., Chadha, S., \& Sharma, A. K. (2015). Operating Liquidity and Financial Leverage: Evidences from Indian Machinery Industry. Procedia - Social and Behavioral Sciences, 189, 344-350. doi:https://doi.org/10.1016/j.sbspro.2015.03.230

Hasan, M. B., Ahsan, A. M., Rahaman, M. A., \& Alam, M. N. (2014). Influence of capital structure on firm performance: Evidence from Bangladesh. International Journal of Business and Management, 9(5), 184.

Ibe, S. O. (2013). The impact of liquidity management on the profitability of banks in Nigeria. Journal of Finance and Bank Management, 1(1), 37-48.

Ibhagui, O. W., \& Olokoyo, F. O. (2018). Leverage and firm performance: New evidence on the role of firm size. The North American Journal of Economics and Finance.

Justyna, Z. (2013). Does liquidity impact on profitability? A case of polish listed IT companies. Paper presented at the Conference of Informatics and Management Sciences.

Khan, A. G. (2012). The relationship of capital structure decisions with firm performance: A study of the engineering sector of Pakistan. International Journal of Accounting and Financial Reporting, 2(1), 245-262.

Lartey, V. C., Antwi, S., \& Boadi, E. K. (2013). The relationship between liquidity and profitability of listed banks in Ghana. International Journal of Business and Social Science, 4(3).

Niresh, J. A. (2012). Trade-off between liquidity \& profitability: A study of selected manufacturing firms in Sri Lanka. Researchers World, 3(4), 34.

Pouraghajan, A., Malekian, E., Emamgholipour, M., Lotfollahpour, V., \& Bagheri, M. M. (2012). The relationship between capital structure and firm performance evaluation measures: Evidence from the Tehran Stock Exchange. International journal of Business and Commerce, 1(9), 166-181.

Raza, M. W. (2013). Affect of financial leverage on firm performance. Empirical evidence from Karachi Stock Exchange.

Robinson, T. R., Henry, E., Pirie, W. L., Broihahn, M. A., \& Cope, A. T. (2015). International Financial Statement Analysis, (CFA Institute Investment Series): John Wiley \& Sons.

Saleem, Q., \& Rehman, R. U. (2011). Impacts of liquidity ratios on profitability. Interdisciplinary Journal of Research in Business, 1(7), 95-98.

Salim, M., \& Yadav, R. (2012). Capital structure and firm performance: Evidence from Malaysian listed companies. Procedia-Social and Behavioral Sciences, 65, 156-166.

Shubita, M. F., \& Alsawalhah, J. M. (2012). The relationship between capital structure and profitability. International Journal of Business and Social Science, 3(16).

Sinha, G. (2012). Financial statement analysis: PHI Learning Pvt. Ltd.

Velnampy, T., \& Nimalathasan, B. (2010). Firm size on profitability: A comparative study of Bank of Ceylon and Commercial Bank of Ceylon Ltd in Srilanka. Global Journal of Management and Business Research, 10(2).

Yeo, H. (2016). Solvency and Liquidity in Shipping Companies. The Asian Journal of Shipping and Logistics, 32(4), 235-241. doi:https://doi.org/10.1016/j.ajsl.2016.12.007 